\title{
Review \\ The Role of Liquid Biopsy in Hepatocellular Carcinoma Prognostication
}

\author{
Ismail Labgaa $^{1}{ }^{1}$, Augusto Villanueva ${ }^{2,3}$, Olivier Dormond ${ }^{1}\left(\mathbb{D}\right.$, Nicolas Demartines $^{1, *} \mathbb{C}^{-}$and Emmanuel Melloul ${ }^{1}$ \\ 1 Department of Visceral Surgery, Lausanne University Hospital (CHUV), University of Lausanne (UNIL), \\ CH-1011 Lausanne, Switzerland; ismail.labgaa@chuv.ch (I.L.); olivier.dormond@chuv.ch (O.D.); \\ emmanuel.melloul@chuv.ch (E.M.) \\ 2 Division of Liver Diseases, Liver Cancer Program, Tisch Cancer Institute, Icahn School of Medicine at Mount \\ Sinai, New York, NY 10029, USA; augusto.villanueva@mssm.edu \\ 3 Division of Hematology/Oncology, Department of Medicine, Icahn School of Medicine at Mount Sinai, \\ New York, NY 10029, USA \\ * Correspondence: demartines@chuv.ch
}

check for updates

Citation: Labgaa, I.; Villanueva, A.; Dormond, O.; Demartines, N.; Melloul, E. The Role of Liquid Biopsy in Hepatocellular Carcinoma Prognostication. Cancers 2021, 13, 659. https://doi.org/10.3390/cancers 13040659

Academic Editor: Alessandro Vitale Received: 26 December 2020

Accepted: 1 February 2021

Published: 6 February 2021

Publisher's Note: MDPI stays neutral with regard to jurisdictional claims in published maps and institutional affiliations.

Copyright: (c) 2021 by the authors. Licensee MDPI, Basel, Switzerland. This article is an open access article distributed under the terms and conditions of the Creative Commons Attribution (CC BY) license (https:// creativecommons.org/licenses/by/ $4.0 /)$.
Simple Summary: Hepatocellular carcinoma (HCC) is one of the deadliest cancer. Clinical guidelines for the management of HCC endorse algorithms deriving from clinical variables whose performances to prognosticate HCC is limited. Liquid biopsy is the molecular analysis of tumor by-products released into the bloodstream. It offers minimally-invasive access to circulating analytes like DNA, RNA, exosomes and cells. This technology demonstrated promising results for various applications in cancers, including prognostication. This review aimed to provide a comprehensive overview of the contribution of liquid biopsy in HCC prognostication. The results suggested that liquid biopsy may be a polyvalent and valuable tool to prognosticate HCC.

Abstract: Showing a steadily increasing cancer-related mortality, the epidemiological evolution of hepatocellular carcinoma (HCC) is concerning. Numerous strategies have attempted to prognosticate HCC but their performance is modest; this is partially due to the heterogeneous biology of this cancer. Current clinical guidelines endorse classifications and scores that use clinical variables, such as the Barcelona Clinic Liver Cancer (BCLC) classification. These algorithms are unlikely to fully recapitulate the genomic complexity of HCC. Integrating molecular readouts on a patient-basis, following a precision-medicine perspective, might be an option to refine prognostic systems. The limited access to HCC tissue samples is an important limitation to these approaches but it could be partially circumvented by using liquid biopsy. This concept consists of the molecular analysis of products derived from a solid tumor and released into biological fluids, mostly into the bloodstream. It offers an easy and minimally-invasive access to DNA, RNA, extracellular vesicles and cells that can be analyzed with next-generation sequencing (NGS) technologies. This review aims to investigate the potential contributions of liquid biopsy in HCC prognostication. The results identified prognostic values for each of the components of liquid biopsy, suggesting that this technology may help refine HCC prognostication.

Keywords: liver cancer; biomarkers; precision medicine; circulating; prognosis

\section{Background}

Hepatocellular carcinoma (HCC) shows a worrisome epidemiological trajectory [1]. The WHO predicts over 1 million HCC-related deaths in 2030 [2]. A particular feature of HCC is that it typically arises on a chronically damaged organ, mostly cirrhosis, for which viral hepatitis, alcohol use disorder and NAFLD are common causes. This facilitates the identification of patients at risk and has enabled successful surveillance programs for early cancer detection. However, having two potentially life-threatening diseases in the same patient (i.e., HCC and cirrhosis) complicates its clinical management and prognosis 
prediction. Numerous attempts have been pursued to reliably prognosticate HCC, using various strategies. The most widely used classifications, like the Barcelona Clinic Liver Cancer (BCLC) algorithm $[3,4]$, relies on clinical variables. Other approaches investigate the contribution of tumor markers like $\alpha$-fetoprotein (AFP) [5] and molecular markers derived from the tumor or adjacent non-tumor samples [6-9]. Regardless of the strategy, the prognostic performance of these algorithms needs to be improved. Following a 'precision medicine' perspective may be a way of improving HCC prognostication. This implies access to genomic data on a patient-basis, which requires biopsy or surgical specimens for tissue samples of the tumor. This is particularly difficult in HCC for which, unlike most solid tumors, diagnosis mostly relies on imaging and tissues samples are rarely available $[10,11]$. In addition, tissue biopsies are associated with potential complications and should not be sequentially repeated [12].

This can be circumvented using liquid biopsy, which refers to the molecular analysis of tumor components released from a solid tumor into biological fluids like blood. These analytes include circulating tumor nucleic acids (DNA and RNAs), cells (CTCs) and exosomes (Figure 1). This technology has shown promising results for various applications in the management of different types of cancers including HCC [13-15]: early diagnosis [16,17], detection of minimal residual disease [18], decision-making for systemic therapies [19,20] or even to decipher complex biological traits of cancers [21-24]. This technology offers a valuable alternative to standard biopsy. Tissue biopsy is indeed invasive and associated with potential risks such as pain, bleeding or even seeding of the cancer (PMID: 18669577). Conversely to standard biopsy, liquid biopsy displays the advantages of being easily repeatable and can thereby help for monitoring, providing a dynamic picture of the disease course. In addition, it may reflect different regions of the tumor and thus recapitulate eventual intra-tumoral heterogeneity (ITH) (Figure 2) [25].

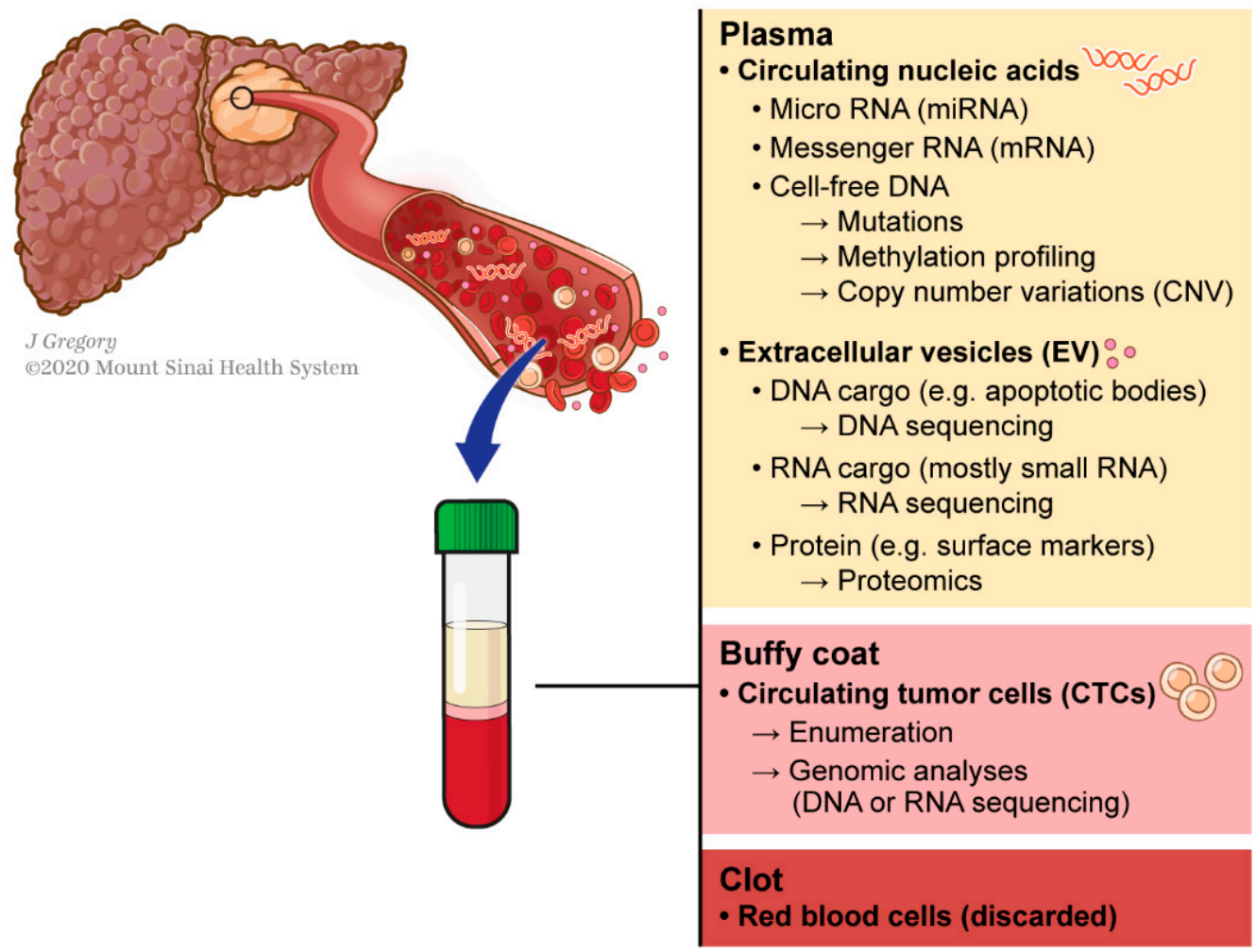

Figure 1. Concept of liquid biopsy referring to the molecular analysis of tumor-byproducts released into the bloodstream. 


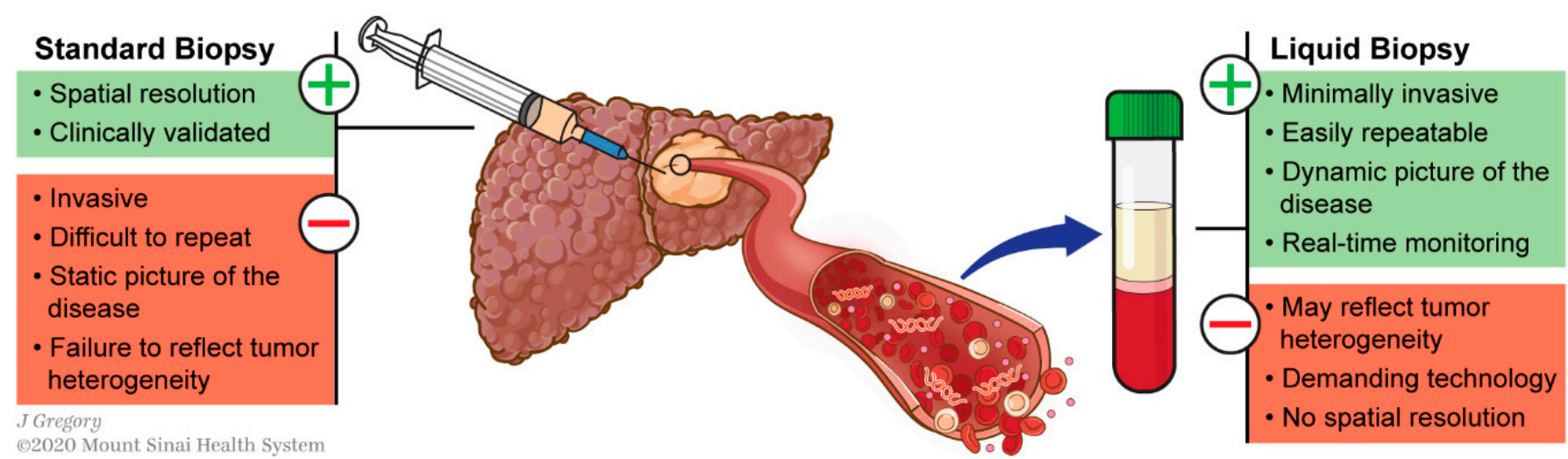

Figure 2. Pros and cons of liquid biopsy versus standard biopsy.

This study aims to provide a comprehensive overview of the potential contributions of each component of liquid biopsy (i.e., DNA, RNAs and cells) to HCC prognostication.

\subsection{Circulating Tumor DNA (ctDNA)}

DNA fragments are released from solid tumors into the bloodstream via active and passive mechanisms. The latter seems to predominate, being partially driven by cell necrosis and apoptosis [26]. This occurs at any tumor stage and offers minimally-invasive access to key molecular information of the tumor including genomic (copy number variations (CNV) or point mutations) as well as epigenetic (DNA methylations changes) data. Numerous studies show the value of ctDNA as a polyvalent biomarker in cancer. For example, ctDNA allowed detection of minimal residual disease (MRD) in a prospective cohort of 230 patients undergoing surgical resection of stage II colon cancer. Postoperative detection of ctDNA outperformed prognostic factors such as TNM stage, for the prediction of recurrence-free survival [18].

In HCC, a pilot study demonstrated that detection of mutations in the plasma of HCC patients was feasible and recapitulated the ones detected in tumor tissue [27]. Table 1 summarizes reports investigating ctDNA in HCC prognostication.

Table 1. Circulating tumor DNA (ctDNA).

\begin{tabular}{|c|c|c|c|c|c|}
\hline $\begin{array}{l}\text { Number of } \\
\text { Patients }\end{array}$ & Treatment & Biomarkers & Technique & Main Finding & [Ref.] \\
\hline \multicolumn{6}{|c|}{$\mathrm{CNV}$} \\
\hline $34 \mathrm{HCC}$ & Surgery & $\begin{array}{l}\text { ctDNA (harboring } \\
\text { SNV or CNV) }\end{array}$ & $\begin{array}{l}\text { Targeted-sequencing } \\
\text { and low coverage } \\
\text { whole-genome } \\
\text { sequencing }\end{array}$ & $\begin{array}{l}\text { ctDNA can detect minimal } \\
\text { residual disease (MRD) and } \\
\text { predict survival }\end{array}$ & [28] \\
\hline $\begin{array}{c}151 \text { HCC; } 14 \\
\text { healthy controls }\end{array}$ & Sorafenib & $\begin{array}{c}V E G F A \\
\text { amplification }\end{array}$ & $\begin{array}{l}\text { Whole-genome } \\
\text { sequencing }\end{array}$ & $\begin{array}{l}\text { High concentration of } \\
\text { cell-free DNA (cfDNA) was } \\
\text { associated with poor } \\
\text { outcomes but VEGFA ratio } \\
\text { was not a prognostic factor. }\end{array}$ & [29] \\
\hline
\end{tabular}


Table 1. Cont

\begin{tabular}{|c|c|c|c|c|c|}
\hline $\begin{array}{l}\text { Number of } \\
\text { Patients }\end{array}$ & Treatment & Biomarkers & Technique & Main Finding & [Ref.] \\
\hline \multicolumn{6}{|c|}{ Mutations } \\
\hline $46 \mathrm{HCC}$ & $\begin{array}{l}\text { Surgery } \\
\text { Transplant }\end{array}$ & ctDNA & $\begin{array}{l}\text { Targeted-sequencing } \\
\text { and exome-sequencing }\end{array}$ & $\begin{array}{l}\text { Detection of ctDNA was } \\
\text { associated with increased } \\
\text { recurrence }\end{array}$ & {$[30]$} \\
\hline $\begin{array}{l}41 \mathrm{HCC} ; 10 \\
\text { controls }\end{array}$ & Surgery & $\begin{array}{l}\text { TERT, TP53 and } \\
\text { CTNNB1 }\end{array}$ & Targeted-sequencing & $\begin{array}{l}\text { Detection of ctDNA } \\
\text { predicted shorter } \\
\text { recurrence-free survival }\end{array}$ & {$[31]$} \\
\hline $10 \mathrm{HCC}$ & $\begin{array}{l}\text { Surgery } \\
\text { TACE } \\
\text { RFA }\end{array}$ & $\begin{array}{l}\text { Methylation of } \\
\text { GSTP1 and } \\
\text { RASSF1A or TP53 } \\
\text { mutation }\end{array}$ & $\begin{array}{l}\text { Methylation-specific } \\
\text { PCR and sanger } \\
\text { sequencing }\end{array}$ & $\begin{array}{l}\text { Detecting ctDNA in urine } \\
\text { was feasible and predicted } \\
\text { recurrence }\end{array}$ & {$[32]$} \\
\hline $\begin{array}{l}218 \mathrm{HCC} ; 81 \\
\text { cirrhotic }\end{array}$ & NA & $\begin{array}{l}\text { TERT promoter } \\
\text { mutation }(\mathrm{C} 228 \mathrm{~T} \\
\text { and C250T) }\end{array}$ & $\begin{array}{c}\text { Droplet digital PCR } \\
\text { (ddPCR) and sanger } \\
\text { sequencing }\end{array}$ & $\begin{array}{l}\text { TERT promoter mutation } \\
\text { can be used as an early } \\
\text { biomarker of HCC and is } \\
\text { associated with survival }\end{array}$ & [33] \\
\hline $34 \mathrm{HCC}$ & Surgery & $\begin{array}{l}\text { ctDNA (harboring } \\
\text { SNV or CNV) }\end{array}$ & $\begin{array}{l}\text { Targeted-sequencing } \\
\text { and low coverage } \\
\text { whole-genome } \\
\text { sequencing }\end{array}$ & $\begin{array}{l}\text { ctDNA can detect minimal } \\
\text { residual disease (MRD) and } \\
\text { predict survival }\end{array}$ & [28] \\
\hline $\begin{array}{l}95 \mathrm{HCC} ; 45 \\
\text { cirrhotic }\end{array}$ & Surgery & $\begin{array}{l}\text { TERT promoter } \\
\text { mutation }(\mathrm{C} 228 \mathrm{~T})\end{array}$ & $\begin{array}{c}\text { Droplet digital PCR } \\
\text { (ddPCR) }\end{array}$ & $\begin{array}{c}\text { Detection of mutated TERT } \\
\text { promoter was associated } \\
\text { with lower survival }\end{array}$ & {$[34]$} \\
\hline $59 \mathrm{HCC}$ & $\begin{array}{c}\text { Surgery } \\
\text { TACE } \\
\text { RFA } \\
\text { Systemic } \\
\text { chemotherapy } \\
\text { BSC }\end{array}$ & $\begin{array}{l}\text { Single nucleotide } \\
\text { variant }(\mathrm{SNV}) \text { in a } \\
\text { panel of } 69 \text { genes }\end{array}$ & Targeted-sequencing & $\begin{array}{l}\text { Mutated MLH1 in plasma } \\
\text { was associated with lower } \\
\text { survival }\end{array}$ & {$[35]$} \\
\hline $130 \mathrm{HCC}$ & $\begin{array}{c}\text { TACE } \\
\text { Systemic } \\
\text { chemotherapy }\end{array}$ & $\begin{array}{l}\text { TERT promoter } \\
\text { mutation }\end{array}$ & $\begin{array}{c}\text { Droplet digital PCR } \\
\text { (ddPCR) }\end{array}$ & $\begin{array}{c}\text { Detection of mutated TERT } \\
\text { promoter was associated } \\
\text { with lower survival }\end{array}$ & [36] \\
\hline 895 HCC & Surgery/NA & $\begin{array}{l}\text { TP53 mutation } \\
\quad \text { (R249S) }\end{array}$ & $\begin{array}{l}\text { Droplet digital PCR } \\
\text { (ddPCR) }\end{array}$ & $\begin{array}{c}\text { Detection of mutated TP53 } \\
\text { was associated with lower } \\
\text { survival }\end{array}$ & [37] \\
\hline $22 \mathrm{HCC}$ & $\begin{array}{c}\text { TKI (tyrosine } \\
\text { kinase inhibitors) }\end{array}$ & $\begin{array}{c}\text { Genes of the } \\
\text { PI3K/MTOR } \\
\text { pathway }\end{array}$ & $\begin{array}{c}\text { Targeted-sequencing } \\
\text { and ddPCR }\end{array}$ & $\begin{array}{l}\text { Mutations of genes in the } \\
\text { PI3K/MTOR pathway are } \\
\text { associated with lower } \\
\text { survival in patients treated } \\
\text { with TKI }\end{array}$ & [38] \\
\hline \multicolumn{6}{|c|}{ Methylation Changes } \\
\hline $\begin{array}{l}72 \text { HCC; } 37 \text { benign } \\
\text { liver diseases; } 41 \\
\text { healthy controls }\end{array}$ & - & $\begin{array}{l}\text { APC, GSTP1, } \\
\text { RASSF1A, and } \\
\text { SFRP1 }\end{array}$ & $\begin{array}{c}\text { Methylation-specific } \\
\text { PCR }\end{array}$ & $\begin{array}{l}\text { Methylation of RASSF1A } \\
\text { was associated with poor } \\
\text { survival }\end{array}$ & [39] \\
\hline $\begin{array}{c}1098 \text { HCC; } 835 \\
\text { controls }\end{array}$ & NA & 8-marker panel & $\begin{array}{l}\text { Targeted bisulfite } \\
\text { sequencing }\end{array}$ & $\begin{array}{l}\text { Methylation-based classifier } \\
\text { predicted survival }\end{array}$ & [40] \\
\hline $10 \mathrm{HCC}$ & $\begin{array}{l}\text { TACE } \\
\text { RFA } \\
\text { Surgery }\end{array}$ & $\begin{array}{l}\text { Methylation of } \\
\text { GSTP1 and } \\
\text { RASSF1A or TP53 } \\
\text { mutation }\end{array}$ & $\begin{array}{l}\text { Methylation-specific } \\
\text { PCR and sanger } \\
\text { sequencing }\end{array}$ & $\begin{array}{l}\text { Detecting ctDNA in urine } \\
\text { was feasible and predicted } \\
\text { recurrence }\end{array}$ & {$[32]$} \\
\hline
\end{tabular}


Table 1. Cont.

\begin{tabular}{|c|c|c|c|c|c|}
\hline $\begin{array}{l}\text { Number of } \\
\text { Patients }\end{array}$ & Treatment & Biomarkers & Technique & Main Finding & [Ref.] \\
\hline \multicolumn{6}{|c|}{ Methylation Changes } \\
\hline $\begin{array}{l}203 \text { HCC; } 104 \\
\text { chronic viral } \\
\text { hepatitis B or C; } 50 \\
\text { healthy controls }\end{array}$ & NA & $\begin{array}{l}\text { APC, COX2, } \\
\text { RASSF1A } \\
(+\mathrm{miR}-203)\end{array}$ & $\begin{array}{c}\text { Methylation-specific } \\
\text { PCR }\end{array}$ & Classifier predicted survival & [41] \\
\hline $172 \mathrm{HCC}$ & NA & LINE-1 & $\begin{array}{c}\text { Methylation-specific } \\
\text { PCR }\end{array}$ & $\begin{array}{c}\text { Hypomethylation of LINE-1 } \\
\text { was associated with lower } \\
\text { survival }\end{array}$ & [42] \\
\hline $\begin{array}{c}155 \mathrm{HCC} ; 60 \\
\text { chronic HBV; } 20 \\
\text { healthy controls }\end{array}$ & Surgery & IGFBP7 & $\begin{array}{c}\text { Methylation-specific } \\
\text { PCR }\end{array}$ & $\begin{array}{l}\text { Methylation of IGFBP7 was } \\
\text { associated with lower } \\
\text { survival }\end{array}$ & [43] \\
\hline $\begin{array}{c}43 \text { HCC (+347 } \\
\text { HCC from TCGA } \\
\text { Atlas); } 5 \text { cirrhotic; } \\
6 \text { benign liver } \\
\text { lesions }\end{array}$ & - & CTCFL & $\begin{array}{c}\text { Methylation-specific } \\
\text { PCR }\end{array}$ & $\begin{array}{l}\text { Hypomethylation of CTCFL } \\
\text { was associated with higher } \\
\text { recurrence and lower } \\
\text { survival }\end{array}$ & {$[44]$} \\
\hline
\end{tabular}

\subsubsection{Copy Number Variations (CNVs)}

CNVs are potential drivers of hepatocarcinogenesis; they predominantly affect chromosomes (chr) 8 and 11 [45]. A pioneer study took advantage of this knowledge and of a mathematical model to infer CNVs using ctDNA in HCC and non-HCC patients [26]. First, it determined the typical size of DNA fragments, approximating $160 \mathrm{bp}$, thereby suggesting that DNA fragments are foremost released by apoptotic cancer cells. Second, the model performed well in distinguishing patients with chronic HBV with and without HCC with an area under the curve (AUC) of 0.93 .

In plasma, a recent study targeted both CNVs and mutations using ctDNA in 34 HCC patients undergoing surgery. CtDNA was reported as a prognostic factor for survival, and it was also able to detect MRD [28]. Another study targeted VEGFA amplification in circulating-free DNA (cfDNA), assuming that it would predict response to sorafenib. Although a high concentration of cfDNA was associated with lower survival, the VEGFA ratio was not a predictor of response to therapy [29].

\subsubsection{Mutations}

The genomic complexity of HCC-characterized by a wide spectrum of different potential driver mutations [46,47]-and the low amount of tumor DNA among the pool of cell free DNA are two major challenges when conducting mutation calling from the plasma of HCC patients. Various techniques can be applied to detect plasma mutations: droplet digital PCR (ddPCR) is better suited to targeting a small number of genes, whereas targeted-sequencing allows investigation of a larger panel of candidates. Although wholegenome sequencing is feasible, it is associated with relatively low coverage, making the interpretation of mutations calling cumbersome.

Several studies focused on TERT promoter, TP53 and CTNNB1, as they are commonly mutated genes in HCC. In a cohort of 41 HCC patients and 10 controls, detection of these mutations was associated with shorter recurrence-free survival after liver resection [31]. This was confirmed by other studies identifying TERT prom and TP53 mutations as prognostic factors of poor survival $[33,34,36,37]$. Targeted-sequencing of various panels of genes further confirmed the prognostic impact of ctDNA detection, associated with worse survival or higher recurrence [30]. Providing more detailed analyses than just the simple presence/absence of ctDNA, Kim et al. showed that MLH1 mutation was specifically associated with lower survival [35], whereas von Felden et al. recently demonstrated that 
mutations of genes from the PI3K/mTOR pathway were predictors of non-response to tyrosine kinase inhibitors (TKI) in patients with advanced HCC [38].

Although most reports used blood samples, liquid biopsy is applicable to other types of biological fluids like urine or saliva. This was illustrated by a study demonstrating the feasibility of detecting mutations in urine samples of HCC patients. Moreover, detection of mutation preceded tumor recurrence as detected by magnetic resonance imaging (MRI) [32].

\subsubsection{DNA Methylation Changes}

The carcinogenic role of epigenetic events like DNA methylation is well known in HCC $[48,49]$. Changes in DNA methylation can also be detected in cfDNA. Similar to mutations, focus can be either on specific candidate or interrogate multiple CpG sites. Several studies identified methylation changes of specific genes associated with HCC outcomes: hypomethylation of LINE-1 [42] and methylation of IGFBP7 [43] were associated with lower survival, whereas hypomethylation of CTCFL predicted higher tumor recurrence and lower survival [44]. A study including $1095 \mathrm{HCC}$ and 835 controls generated a classifier of 8 markers for diagnosis and prognosis (SH3PXD2A, C11orf9, PPFIA1, Chr 17:78, SERPINB5, NOTCH3, GRHL2 and TMEM8B). In addition to providing a high diagnostic accuracy, the score was also associated with survival [40]. Two other studies used comparable approaches and provided similar findings $[39,41]$.

\subsection{Circulating Free RNAs (cfRNAs)}

RNAs include a large family of members: micro, long non-coding, messenger or exosomal RNAs. Herein, the present review will focus on the most commonly investigated circulating RNAs in liquid biopsies (Table 2).

Table 2. Circulating free RNAs (cfRNAs) and exosomes.

\begin{tabular}{|c|c|c|c|c|c|}
\hline $\begin{array}{l}\text { Number of } \\
\text { Patients }\end{array}$ & Treatment & Biomarkers & Technique & Main Finding & [Ref.] \\
\hline \multicolumn{6}{|c|}{ miRNA } \\
\hline $\begin{array}{l}195 \mathrm{HCC} \\
54 \text { cirrhotic }\end{array}$ & $\begin{array}{l}\text { Surgery } \\
\text { Transplant } \\
\text { TACE } \\
\text { RFA } \\
\text { sorafenib }\end{array}$ & miR-1 and miR-12 & qRT-PCR & $\begin{array}{l}\text { Low level of miR-1 was } \\
\text { associated with lower survival }\end{array}$ & {$[50]$} \\
\hline $122 \mathrm{HCC}$ & Surgery & miR-122 & qRT-PCR & $\begin{array}{l}\text { Low level of miR-122 was } \\
\text { associated with lower survival }\end{array}$ & [51] \\
\hline $120 \mathrm{HCC}$ & $\begin{array}{l}\text { Surgery } \\
\text { RFA }\end{array}$ & $\begin{array}{l}\text { MiR-21, miR-26a, } \\
\text { and miR-29a }\end{array}$ & qRT-PCR & $\begin{array}{c}\text { Low levels of miR-26a and } \\
\text { miR-29a were associated with } \\
\text { lower survival }\end{array}$ & [52] \\
\hline $\begin{array}{l}30 \mathrm{HCC} ; 30 \\
\text { controls }\end{array}$ & Surgery & $\begin{array}{l}\text { miR-155, miR-96 } \\
\text { and miR-99a }\end{array}$ & qRT-PCR & $\begin{array}{l}\text { High levels of miR-155 and } \\
\text { miR-96 were associated with } \\
\text { lower survival }\end{array}$ & [53] \\
\hline $116 \mathrm{HCC}$ & NA & Circulating miR & $\begin{array}{l}\text { Whole miRNome } \\
\text { profling }\end{array}$ & $\begin{array}{l}\text { Low levels of miR-424-5p, } \\
\text { miR-101-3p or high levels of } \\
\text { miR-128, miR-139-5p, } \\
\text { miR-382-5p and miR410 were } \\
\text { associated with lower survival }\end{array}$ & [54] \\
\hline $\begin{array}{l}41 \mathrm{HCC} ; 20 \\
\text { controls }\end{array}$ & $\begin{array}{l}\text { Surgery } \\
\text { transplant }\end{array}$ & miR193a-5p & qRT-PCR & $\begin{array}{l}\text { High level of miR193a-5p was } \\
\text { associated with lower survival }\end{array}$ & [55] \\
\hline $\begin{array}{c}70 \text { HBV-related } \\
\text { HCC } \\
70 \mathrm{HBV} \\
50 \text { healthy controls }\end{array}$ & Surgery & miRNA-223-3p & qRT-PCR & $\begin{array}{c}\text { Low level of miRNA-223-3p } \\
\text { was associated with lower } \\
\text { survival }\end{array}$ & {$[56]$} \\
\hline
\end{tabular}


Table 2. Cont

\begin{tabular}{|c|c|c|c|c|c|}
\hline $\begin{array}{c}\text { Number of } \\
\text { Patients }\end{array}$ & Treatment & Biomarkers & Technique & Main Finding & [Ref.] \\
\hline \multicolumn{6}{|c|}{ mRNA } \\
\hline $\begin{array}{l}50 \text { HCC; } 50 \\
\text { controls }\end{array}$ & Surgery & VEGF-165 & qRT-PCR & $\begin{array}{l}\text { Detection of circulating VEGF } \\
\text { mRNA (isoform 165) was } \\
\text { associated with higher } \\
\text { recurrence and } \\
\text { recurrence-related mortality }\end{array}$ & [57] \\
\hline $38 \mathrm{HCC}$ & Surgery & AFP & qRT-PCR & $\begin{array}{l}\text { Detection of AFP mRNA was } \\
\text { associated with extrahepatic } \\
\text { recurrence and shorter } \\
\text { disease-free survival }\end{array}$ & [58] \\
\hline $343 \mathrm{HCC}$ & $\begin{array}{c}\text { Surgery } \\
\text { TACE } \\
\text { RFA } \\
\text { Systemic } \\
\text { chemotherapy } \\
\text { Radiotherapy } \\
\text { BSC }\end{array}$ & AFP and hTERT & qRT-PCR & $\begin{array}{l}\text { Detection of AFP mRNA or } \\
\text { hTERT mRNA was not } \\
\text { associated with survival }\end{array}$ & [59] \\
\hline \multicolumn{6}{|c|}{ Exosomes } \\
\hline $59 \mathrm{HCC}$ & Transplant & miR-718 & qRT-PCR & $\begin{array}{c}\text { Recurrence was associated } \\
\text { with higher level of exosomal } \\
\text { miR-718 }\end{array}$ & {$[60]$} \\
\hline $30 \mathrm{HCC}$ & Surgery & miR-665 & qRT-PCR & $\begin{array}{c}\text { High level of exosomal } \\
\text { miR-665 was associated with } \\
\text { lower survival }\end{array}$ & {$[61]$} \\
\hline $79 \mathrm{HCC}$ & $\begin{array}{c}\text { Surgery } \\
\text { Transplant } \\
\text { TACE } \\
\text { RFA } \\
\text { Sorafenib } \\
\text { BSC }\end{array}$ & $\begin{array}{l}\text { miR-21 and } \\
\text { lncRNA-ATB }\end{array}$ & qRT-PCR & $\begin{array}{c}\text { High levels of exosomal } \\
\text { miR-21 and lncRNA-ATB } \\
\text { were associated with lower } \\
\text { survival }\end{array}$ & [62] \\
\hline $\begin{array}{c}126 \text { HCC; } 21 \\
\text { healthy controls }\end{array}$ & Surgery & miR-638 & qRT-PCR & $\begin{array}{c}\text { Low level of exosomal } \\
\text { miR-638 was associated with } \\
\text { lower survival }\end{array}$ & [63] \\
\hline $\begin{array}{l}31 \text { HCC; } 3 \text { CLD; } 11 \\
\text { healthy controls }\end{array}$ & NA & $\begin{array}{l}\text { RN7SL1 S } \\
\text { fragment }\end{array}$ & qRT-PCR & $\begin{array}{l}\text { High expression of RN7SL1 S } \\
\text { fragment was associated with } \\
\text { lower survival }\end{array}$ & [64] \\
\hline $\begin{array}{c}124 \text { HCC; } 100 \\
\text { healthy controls }\end{array}$ & Surgery & AKT3 & qRT-PCR & $\begin{array}{c}\text { High level of exosomal } \\
\text { circulating AKT3 was } \\
\text { associated with higher } \\
\text { recurrence and lower survival } \\
\text { rates }\end{array}$ & [65] \\
\hline $\begin{array}{l}104 \text { HCC; } 55 \text { CLD; } \\
50 \text { healthy controls }\end{array}$ & Surgery & miR-320a & qRT-PCR & $\begin{array}{c}\text { Low serum exosomal } \\
\text { miR-320a was associated with } \\
\text { lower survival }\end{array}$ & [66] \\
\hline
\end{tabular}

\subsubsection{Micro-RNAs (miRNAs)}

MiRNAs have gained increased interest as cancer biomarkers, as they have key properties, in particular their molecular stability. Lin et al. established a classifier based on seven miRNAs, which was able to detect preclinical HCC [67]. This could be a valuable tool for HCC surveillance, which could outperform the recommended bi-annual ultrasound (US) and AFP measurement. 
A number of circulating miRNAs have shown prognostic value in HCC. Low levels of miR-1, miR-122, miR-26a, miR-29a and miR-223-3p were associated with lower survival $[50-52,56]$. Patients with high levels of miR-155, miR-96 and miR-193-5p had lower survival rates [53,55]. A recent study reported whole miRNome profiling in 116 HCC patients [54]. Using three different cohorts, the study reported on miRNAs differentially expressed in HCC vs. non-HCC patients. This effort identified miRNAs with specific clinical utilities; certain biomarkers detected cirrhosis, while others detected HCC. Furthermore, six miRNAs were identified as prognostic factors. Down-regulation of miR-424-5p or miR101-3p and up-regulated miR-128, miR-139-5p, miR-382-5p and miR410 were associated with lower survival.

\subsubsection{Messenger RNAs (mRNAs)}

Unlike miRNAs, circulating mRNAs are highly unstable and are thus rarely explored as liquid biopsy analytes. Studies attempting to measure mRNAs in blood samples analyzed a limited number of candidates.

A comparison of $50 \mathrm{HCC}$ patients and 50 controls detected an association between VEGF expression level (isoform 165) and the risk of tumor recurrence [57]. The concentration of circulating mRNAs coding for AFP was investigated in two other studies. The first one included $38 \mathrm{HCC}$ patients undergoing partial resection and showed that detection of AFP mRNA was associated with extrahepatic recurrence and shorter disease-free survival [58]. The second one tested both levels of AFP and hTERT mRNAs, but failed to identify any prognostic impact [59].

\subsection{Extracellular Vesicles (EVs): Exosomes}

Exosomes are a type of EV, nanoparticles encapsulating a variety of cargo including DNA and RNA fragments in a lipidic double-layer, which protects them from enzymatic degradation. With these unique features, circulating exosomes allow RNAs to circulate without being degraded plasma. Their nature and roles remain largely unknown but exosomes may not only be passively released from apoptotic cells into the bloodstream. Data suggested they may be actively secreted, acting as messengers in the cell-to-cell communication network, conferring them priceless values like accuracy and tissue-specificity [68-71].

In HCC, the data exploring the contribution of exosomes remain limited, particularly for prognosis. However, these analytes have demonstrated promising and polyvalent performance in other cancer types both for diagnosis and prognosis [72,73].

Several projects analyzed exosomal miRNAs. In a cohort of 59 HCC patients, authors found a correlation between tumor recurrence after liver transplantation and a higher level of miR-718 [60]. Similar signals were detected after liver resection and other exosomal miRNAs: high levels of miR-665 or low levels of miR-638 and miR-320a were identified as predictors of poor survival $[61,63,66]$. In a cohort of 79 HCC patients of different stages receiving various treatments, Lee et al. focused on two candidates: a miRNA (miR-21) and a long non-coding RNA (lncRNA) (lncRNA-ATB). On multivariable analysis, both markers were independently associated with disease progression [62]. A recent study profiled 57 plasma cell-free RNA transcriptomes and 20 exosomal RNA transcriptomes to test their diagnostic and prognostic performance. RN7SL1 and its S fragment were promising, showing a high diagnostic accuracy $(\mathrm{AUC}=0.87)$. Furthermore, a higher concentration of RN7SL1 S fragment was an independent factor of worse survival [64]. The analyses of blood samples from $124 \mathrm{HCC}$ patients treated with surgical resection and 100 healthy controls identified an exosomal circular RNA (circAKT3) as a prognostic factor; a high level of circAKT3 predicted both higher recurrence and lower survival [65].

\subsection{Circulating Tumor Cells (CTCs)}

CTCs play a pivotal role during the hematogenous dissemination of cancers. Most technologies to analyze CTCs include two steps: enrichment (isolation) and detection (identification). The development of sensitive and specific technologies is challenging. 
Estimated to be released by cancers of intermediate and advanced stages, CTCs are probably more useful for prognostication than for early cancer detection. In this context, studies have demonstrated the prognostic value of CTC enumeration in different cancers including HCC [74,75]. More sophisticated technologies, like single-cell RNA sequencing, have allowed further characterization of CTC subtypes [76]. Studies exploring the value of CTCs for HCC prognostication are summarized in Table 3.

Table 3. Circulating tumor cells (CTCs).

\begin{tabular}{|c|c|c|c|c|}
\hline Number of Patients & Treatment & Technique of Detection & Main Finding & [Ref.] \\
\hline $\begin{array}{c}44 \mathrm{HCC} \\
30 \mathrm{HCV} \\
39 \text { cirrhosis } \\
38 \text { healthy controls }\end{array}$ & $\begin{array}{l}\text { Surgery } \\
\text { NA }\end{array}$ & $\begin{array}{l}\text { Isolation by size of } \\
\text { epithelial tumor cells } \\
\text { (ISET) }\end{array}$ & $\begin{array}{c}\text { Presence and number of detected } \\
\text { CTCs were associated with shorter } \\
\text { survival }\end{array}$ & [77] \\
\hline $\begin{array}{c}85 \mathrm{HCC} \\
37 \text { benign liver diseases } \\
20 \text { healthy volunteers } \\
14 \text { miscellaneous } \\
\text { advanced cancers other } \\
\text { than HCC }\end{array}$ & $\begin{array}{l}\text { Surgery } \\
\text { NA }\end{array}$ & $\begin{array}{l}\text { Antibody-coated magnetic } \\
\text { beads }\end{array}$ & $\begin{array}{l}\text { Presence and number of detected } \\
\text { CTCs correlated with tumor size, } \\
\text { portal vein tumor thrombus, } \\
\text { differentiation status, TNM stage and } \\
\text { Milan criteria }\end{array}$ & [78] \\
\hline $82 \mathrm{HCC}$ & Surgery & Multicolor flow cytometry & $\begin{array}{l}\text { Circulating cancer stem cells (CSC) are } \\
\text { associated with higher rates of intra- } \\
\text { and extra-hepatic recurrence, } \\
\text { decreased recurrence-free survival } \\
\text { (RFS) and overall survival (OS) rates }\end{array}$ & [79] \\
\hline $\begin{array}{l}96 \mathrm{HCC} \\
31 \text { healthy controls } \\
21 \text { viral hepatitis } \\
8 \text { cirrhosis }\end{array}$ & Surgery & $\begin{array}{l}\text { Magnetic cell sorting } \\
\qquad(\text { Lin28B) }\end{array}$ & $\begin{array}{l}\text { Detection of CTCs expressing Lin28B } \\
\text { was associated with early recurrence }\end{array}$ & [80] \\
\hline $60 \mathrm{HCC}$ & $\begin{array}{l}\text { Surgery } \\
\text { NA }\end{array}$ & Flow cytometry (ICAM-1) & $\begin{array}{c}\text { Detection of CTCs expressing ICAM-1 } \\
\text { was associated with shorter } \\
\text { disease-free survival }\end{array}$ & [81] \\
\hline $123 \mathrm{HCC}$ & Surgery & $\begin{array}{l}\text { EpCAM antibody-coated } \\
\text { magnetic beads } \\
\text { (CellSearch) }\end{array}$ & $\begin{array}{l}\text { Detection of CTCs (EpCAM+) was } \\
\text { associated with higher recurrence }\end{array}$ & [75] \\
\hline $\begin{array}{l}59 \text { HCC } \\
19 \text { controls }\end{array}$ & NA & $\begin{array}{l}\text { EpCAM antibody-coated } \\
\text { magnetic beads } \\
\text { (CellSearch) }\end{array}$ & $\begin{array}{l}\text { Detection of CTCs was associated } \\
\text { with lower overall survival }\end{array}$ & [82] \\
\hline $\begin{array}{l}122 \mathrm{HCC} \\
120 \text { controls }\end{array}$ & $\begin{array}{c}\text { Surgery } \\
\text { TACE } \\
\text { Radiotherapy }\end{array}$ & $\begin{array}{l}\text { EpCAM antibody-coated } \\
\text { magnetic beads } \\
\text { (CellSearch) }\end{array}$ & $\begin{array}{l}\text { Peri-treatment decrease of detected } \\
\text { CTC reflected treatment response }\end{array}$ & [83] \\
\hline $109 \mathrm{HCC}$ & $\begin{array}{l}\text { Surgery } \\
\text { TACE } \\
\text { RFA } \\
\text { sorafenib }\end{array}$ & $\begin{array}{c}\text { Flow cytometry (ASGPR } \\
\text { and CPS1) }\end{array}$ & $\begin{array}{l}\text { pERK+/pAkt-CTCs correlated with } \\
\text { progression-free survival and } \\
\text { predicted response to systemic } \\
\text { therapy (sorafenib) }\end{array}$ & [84] \\
\hline $72 \mathrm{HCC}$ & Surgery & $\begin{array}{l}\text { EpCAM antibody-coated } \\
\text { magnetic nanoparticals } \\
\text { (MagVigen, Nvigen) }\end{array}$ & $\begin{array}{c}\text { Detection of CTCs expressing AFP } \\
\text { was associated with metastatic disease }\end{array}$ & [85] \\
\hline $\begin{array}{l}69 \mathrm{HCC} \\
31 \text { controls }\end{array}$ & $\begin{array}{l}\text { Surgery } \\
\text { Transplant } \\
\text { TACE } \\
\text { RFA } \\
\text { Sorafenib } \\
\text { BSC }\end{array}$ & $\begin{array}{l}\text { Imaging flow cytometry } \\
\text { (EpCAM, AFP, glypican-3 } \\
\text { and DNA-PK together } \\
\text { with analysis of size, } \\
\text { morphology and DNA } \\
\text { content) (ImageStream) }\end{array}$ & $\begin{array}{c}\text { Detection of CTCs was associated } \\
\text { with lower survival }\end{array}$ & {$[86]$} \\
\hline
\end{tabular}


Table 3. Cont.

\begin{tabular}{|c|c|c|c|c|}
\hline Number of Patients & Treatment & Technique of Detection & Main Finding & [Ref.] \\
\hline $57 \mathrm{HCC}$ & Surgery & $\begin{array}{l}\text { EpCAM antibody-coated } \\
\text { magnetic beads } \\
\text { (CellSearch) }\end{array}$ & $\begin{array}{l}\text { CTCs detection was associated with } \\
\text { higher recurrence and lower } \\
\text { recurrence-free survival after liver } \\
\text { resection }\end{array}$ & [87] \\
\hline $\begin{array}{l}14 \mathrm{HCC} \\
16 \mathrm{CCA} \\
4 \mathrm{GBC}\end{array}$ & Surgery & SE-iFISH & $\begin{array}{c}\text { Detection of small CTCs with CNV } \\
\text { (chromosome } 8 \text { ) was associated with } \\
\text { lower survival }\end{array}$ & [88] \\
\hline $199 \mathrm{HCC}$ & Surgery & $\begin{array}{l}\text { Fluorescence-activated cell } \\
\text { sorting (FACS) }\end{array}$ & $\begin{array}{c}\text { Anterior approach was associated } \\
\text { with a decreased dissemination of } \\
\text { CTCs compared to conventional } \\
\text { approach, resulting in poorer } \\
\text { outcomes. }\end{array}$ & [89] \\
\hline $73 \mathrm{HCC}$ & Surgery & $\begin{array}{l}\text { EpCAM antibody-coated } \\
\text { magnetic beads } \\
\text { (CellSearch) }\end{array}$ & $\begin{array}{l}\text { Analyzes of blood samples collected } \\
\text { in different vessels revealed a spatial } \\
\text { heterogeneity of CTCs distribution } \\
\text { whose biology was associated with } \\
\text { recurrence pattern. }\end{array}$ & [90] \\
\hline $130 \mathrm{HCC}$ & $\begin{array}{l}\text { Surgery } \\
\text { TACE }\end{array}$ & qRT-PCR test platform & $\begin{array}{l}\text { CTCs detection was associated with } \\
\text { recurrence after liver resection }\end{array}$ & [91] \\
\hline $112 \mathrm{HCC}$ & Surgery & $\begin{array}{l}\text { CanPatrolTM system } \\
\text { (filtration by size) and } \\
\text { Tri-color RNA-ISH assay }\end{array}$ & $\begin{array}{l}\text { The presence of CTCs and the } \\
\text { proportion of mesenchymal-CTC } \\
\text { (M-CTCs) were associated with } \\
\text { recurrence }\end{array}$ & [92] \\
\hline $\begin{array}{c}61 \mathrm{HCC} \\
19 \text { non-HCC }\end{array}$ & $\begin{array}{c}\text { TACE } \\
\text { TARE } \\
\text { RFA } \\
\text { Systemic therapy }\end{array}$ & Antibody-based platform & $\begin{array}{l}\text { Vimentin (VIM)-positive CTCs } \\
\text { predicted OS and faster recurrence } \\
\text { after curative-intent surgical or } \\
\text { locoregional therapy in potentially } \\
\text { curable early-stage HCC }\end{array}$ & [93] \\
\hline $\begin{array}{l}139 \text { HCC } \\
23 \text { controls }\end{array}$ & Surgery & $\begin{array}{l}\text { EpCAM antibody-coated } \\
\text { magnetic beads } \\
\text { (CellSearch) }\end{array}$ & $\begin{array}{l}\text { Surgical resection induces a release of } \\
\text { CTCs }\end{array}$ & [94] \\
\hline $105 \mathrm{HCC}$ & Surgery & ISET & $\begin{array}{l}\triangle \mathrm{CTCs} \text { is an independent predictor of } \\
\text { lower survival and higher recurrence } \\
\text { in patients }\end{array}$ & [95] \\
\hline $\begin{array}{c}85 \mathrm{HCC} \\
27 \text { non-HCC }\end{array}$ & Surgery & Flow cytometry (GPC3) & $\begin{array}{l}\text { GPC3 positive-CTCs detection was } \\
\text { associated with lower survival }\end{array}$ & [96] \\
\hline $50 \mathrm{HCC}$ & Transplant & $\begin{array}{l}\text { Negative enrichment and } \\
\text { immunofluorescence in } \\
\text { situ hybridization } \\
\text { (imFISH) }\end{array}$ & $\begin{array}{l}\text { CTCs detection was associated with } \\
\text { early recurrence after liver transplant }\end{array}$ & [97] \\
\hline $137 \mathrm{HCC}$ & Surgery & ISET & $\begin{array}{l}\text { CTCs detection was associated with } \\
\text { early recurrence after liver resection }\end{array}$ & [98] \\
\hline $\begin{array}{c}87 \mathrm{HCC} \\
7 \text { cirrhosis } \\
8 \text { healthy controls }\end{array}$ & $\begin{array}{c}\text { Transplant } \\
\text { Surgery } \\
\text { TACE } \\
\text { TARE } \\
\text { RFA } \\
\text { Systemic therapy }\end{array}$ & Antibody-based platform & $\begin{array}{l}\text { Detection of CTCs expressing PD-L1 } \\
\text { were associated with shorter OS and } \\
\text { predicted response to immunotherapy }\end{array}$ & [99] \\
\hline $128 \mathrm{HCC}$ & Surgery \pm TACE & $\begin{array}{l}\text { EpCAM antibody-coated } \\
\text { magnetic beads } \\
\text { (CellSearch) }\end{array}$ & $\begin{array}{l}\text { Adjuvant TACE provided survival } \\
\text { and recurrence benefits in patients } \\
\text { with positive preoperative CTCs }\end{array}$ & [100] \\
\hline $193 \mathrm{HCC}$ & Transplant & $\begin{array}{l}\text { Antibody-based platform } \\
\text { (ChimeraX®-i120) }\end{array}$ & $\begin{array}{l}\text { CTCs detection was associated with } \\
\text { recurrence after liver transplant }\end{array}$ & [101] \\
\hline
\end{tabular}


Most studies investigating CTCs included HCC patients undergoing surgical resection. In 2004, Vona G et al. isolated and enumerated CTCs based on their size and morphology, showing that the presence and number of detected CTCs were associated with shorter survival [77]. CellSearch ${ }^{\circledR}$ is an isolation system that targets EpCAM positive cells. It was approved by the Food and Drug Administration (FDA) and became the most commonly used technique for CTC enumeration. Its use remains debated in HCC as only around 30\% of HCC cells express EpCAM [102]. Nonetheless, several studies utilized this approach in HCC, demonstrating that the detection of EpCAM positive CTCs was associated with higher tumor recurrence [75] or lower survival [82,87]. Thereafter, more sophisticated technologies for CTC isolation have been reported, like ImageStream flow cytometry. A study has provided the proof-of-concept of this technology, demonstrating its capacity to detect CTCs using a panel of markers. This technology also generates high-resolution images of isolated CTCs [103]. Its value in detecting CTCs was confirmed and the CTC count was further confirmed as an independent prognostic factor [86]. Other reports have aimed at exploring the impact of subgroups of CTCs, clustered based on cell surface markers, RNA expression or genomic aberrations. Studies using surface markers to detect CTCs with cancer stem cell-like [79-81] or mesenchymal [92] features, revealed their clinical value to predict tumor recurrence. CTCs expressing AFP were also associated with an increased risk of metastasis [85], whereas CTCs harboring CNV (chr 8) predicted worse survival [88]. Ha et al. used a simple isolation technique but introduced the concept of $\triangle C T C$, referring to the perioperative fluctuation of detected CTCs, which appeared as an independent factor of lower survival and higher recurrence rates after partial hepatectomy [95]. Besides their intrinsic biological traits, CTC dissemination seemed to be impacted by treatment. Data suggested that surgery-induced manipulation of the liver is associated with a release of CTCs [94]. A comparison between anterior and conventional surgical approaches suggested that the latter was associated with a higher release of CTCs as well as poorer outcomes [89]. Toso et al. described five steps during orthotopic liver transplant (OLT) in HCC patients to minimize CTC dissemination and thereby the risk of recurrence [104].

Recent studies also underscored the relevance of CTC analysis in patients undergoing OLT for HCC, highlighting an association between CTC detection and recurrence [97,101].

Guiding decision-making would be another application of CTCs. For example, selection of patients who would benefit from adjuvant transarterial chemoembolization (TACE) after surgery or to predict response to systemic therapies like tyrosine kinase inhibitors or immunotherapy $[84,99,100]$. An interesting study analyzed CTCs using samples collected from different vessels. By doing so, they were able to demonstrate spatial heterogeneity in the distribution of CTCs, with a predominance of epithelial status at release, which gradually switched to EMT-activated phenotype during hematogenous transit [90]. Overall, data consistently identified that the number of CTCs was a surrogate of poor prognosis, predicting higher recurrence and/or lower survival. A recent meta-analysis and data from experimental models corroborated these findings [105,106].

\section{Challenges and Future Perspectives}

The field of liquid biopsy has numerous challenges. Besides those related to cost and technology, there is a limited understanding of the fundamental mechanisms responsible for the release of tumor molecular components to the bloodstream. A better understanding of these mechanisms would provide new tools and targets to improve the diagnostic and prognostic performance of liquid biopsy analytes. Gasparello et al. performed one of the few studies of liquid biopsies in animal models, identifying potential gateways regulating the detection of ctDNA [107]. Experimental models will be instrumental to better understand these mechanisms. ITH has emerged as a major drawback for singlebiopsy biomarker development. The clinical impact of ITH is progressively recognized, even at early tumor stages [108]. Liquid biopsy can help address the clinical issues posed by ITH as it likely includes a molecular composite of tumor components released by any 
potential tumor area. Thus, it is not restricted by the specific tumor section sampled by a needle-biopsy. There are few data of integrative analysis of different analytes within the liquid biopsy space (e.g., simultaneous evaluation of ctDNA and CTCs). Finally, it is key to have prospective data to determine the exact role of liquid biopsy as a prognostic biomarker in HCC, and which is the clinical niche that will be better suited for this transformative technology.

\section{Conclusions}

While data on liquid biopsy in HCC remain scanter than for other malignancies, there has been numerous recent publications demonstrating its prognostic value in HCC patients. Potential contributions in HCC prognostication were detected for each of the tumor byproducts (e.g., DNA, RNA, exosomes and cells). The next step will be to determine the optimal way of integrating liquid biopsy in the clinical management of HCC patients and to modify current clinical practice guidelines accordingly.

Author Contributions: Study concept and design: I.L., A.V., O.D., N.D., E.M.; Acquisition of data: I.L.; Analysis and interpretation of data: I.L., A.V., E.M.; Drafting of the manuscript: I.L.; Critical revision of the manuscript for important intellectual content: I.L., A.V., O.D., N.D., E.M. All authors have read and agreed to the published version of the manuscript.

Funding: This research received no external funding.

Acknowledgments: The authors would like to thank Jill Gregory for the design of the figures.

Conflicts of Interest: AV has received consulting fees from Guidepoint, Fujifilm, Boehringer Ingelheim, FirstWord, and MHLife Sciences; advisory board fees from Exact Sciences, Nucleix, Gilead and NGM Pharmaceuticals; and research support from Eisai.

\section{References}

1. Villanueva, A. Hepatocellular Carcinoma. N. Engl. J. Med. 2019, 380, 1450-1462. [CrossRef] [PubMed]

2. World Health Organization. Projections of Mortality and Causes of Death, 2016 to 2060. Available online: http:/ / www.who.int/ healthinfo/global_burden_disease/projections/en/ (accessed on 14 October 2018).

3. Llovet, J.M.; Bru, C.; Bruix, J. Prognosis of hepatocellular carcinoma: The BCLC staging classification. Semin. Liver. Dis. 1999, 19, 329-338. [CrossRef] [PubMed]

4. Bruix, J.; Sherman, M.; American Association for the Study of Liver Diseases. Management of hepatocellular carcinoma: An update. Hepatology 2011, 53, 1020-1022. [CrossRef] [PubMed]

5. He, C.; Peng, W.; Liu, X.; Li, C.; Li, X.; Wen, T.F. Post-treatment alpha-fetoprotein response predicts prognosis of patients with hepatocellular carcinoma: A meta-analysis. Medicine (Baltimore) 2019, 98, e16557. [CrossRef] [PubMed]

6. Labgaa, I.; Torrecilla, S.; Martinez-Quetglas, I.; Sia, D. Genetics of Hepatocellular Carcinoma: Risk Stratification, Clinical Outcome, and Implications for Therapy. Digest. Disease Interv. 2017, 01, 055-065. [CrossRef]

7. Goossens, N.; Labgaa, I.; Villanueva, A. Nontumor Prognostic Factors in Hepatocellular Carcinoma. In Hepatocellular Carcinoma. Current Clinical Oncology; Carr, B.I., Ed.; Springer: Cham, Switzerland, 2016. [CrossRef]

8. Hoshida, Y.; Villanueva, A.; Kobayashi, M.; Peix, J.; Chiang, D.Y.; Camargo, A.; Gupta, S.; Moore, J.; Wrobel, M.J.; Lerner, J.; et al. Gene expression in fixed tissues and outcome in hepatocellular carcinoma. N. Engl. J. Med. 2008, 359, 1995-2004. [CrossRef] [PubMed]

9. Villanueva, A.; Hoshida, Y.; Battiston, C.; Tovar, V.; Sia, D.; Alsinet, C.; Cornella, H.; Liberzon, A.; Kobayashi, M.; Kumada, H.; et al. Combining clinical, pathology, and gene expression data to predict recurrence of hepatocellular carcinoma. Gastroenterology 2011, 140, 1501-1512. [CrossRef] [PubMed]

10. European Association for the Study of the Liver. EASL Clinical Practice Guidelines: Management of hepatocellular carcinoma. J. Hepatol. 2018, 69, 182-236. [CrossRef]

11. Heimbach, J.K.; Kulik, L.M.; Finn, R.S.; Sirlin, C.B.; Abecassis, M.M.; Roberts, L.R.; Zhu, A.X.; Murad, M.H.; Marrero, J.A. AASLD guidelines for the treatment of hepatocellular carcinoma. Hepatology 2018, 67, 358-380. [CrossRef] [PubMed]

12. Silva, M.A.; Hegab, B.; Hyde, C.; Guo, B.; Buckels, J.A.; Mirza, D.F. Needle track seeding following biopsy of liver lesions in the diagnosis of hepatocellular cancer: A systematic review and meta-analysis. Gut 2008, 57, 1592-1596. [CrossRef]

13. Labgaa, I.; Villanueva, A. Liquid biopsy in liver cancer. Discov. Med. 2015, 19, 263-273.

14. von Felden, J.; Garcia-Lezana, T.; Schulze, K.; Losic, B.; Villanueva, A. Liquid biopsy in the clinical management of hepatocellular carcinoma. Gut 2020, 69, 2025-2034. [CrossRef] 
15. Labgaa, I.; Craig, A.J.; Villanueva, A. Diagnostic and Prognostic Performance of Liquid Biopsy in Hepatocellular Carcinoma. In Liquid Biopsy in Cancer Patients. Current Clinical Pathology; Giordano, A., Rolfo, C., Russo, A., Eds.; Humana Press: Cham, Switzerland, 2017. [CrossRef]

16. Cohen, J.D.; Li, L.; Wang, Y.; Thoburn, C.; Afsari, B.; Danilova, L.; Douville, C.; Javed, A.A.; Wong, F.; Mattox, A.; et al. Detection and localization of surgically resectable cancers with a multi-analyte blood test. Science 2018, 359, 926-930. [CrossRef]

17. Bettegowda, C.; Sausen, M.; Leary, R.J.; Kinde, I.; Wang, Y.; Agrawal, N.; Bartlett, B.R.; Wang, H.; Luber, B.; Alani, R.M.; et al. Detection of circulating tumor DNA in early- and late-stage human malignancies. Sci. Transl. Med. 2014, 6, 224. [CrossRef] [PubMed]

18. Tie, J.; Wang, Y.; Tomasetti, C.; Li, L.; Springer, S.; Kinde, I.; Silliman, N.; Tacey, M.; Wong, H.L.; Christie, M.; et al. Circulating tumor DNA analysis detects minimal residual disease and predicts recurrence in patients with stage II colon cancer. Sci. Transl. Med. 2016, 8, 346. [CrossRef]

19. Tie, J.; Cohen, J.D.; Wang, Y.; Christie, M.; Simons, K.; Lee, M.; Wong, R.; Kosmider, S.; Ananda, S.; McKendrick, J.; et al. Circulating Tumor DNA Analyses as Markers of Recurrence Risk and Benefit of Adjuvant Therapy for Stage III Colon Cancer. JAMA Oncol. 2019. [CrossRef]

20. Lee, B.; Lipton, L.; Cohen, J.; Tie, J.; Javed, A.A.; Li, L.; Goldstein, D.; Burge, M.; Cooray, P.; Nagrial, A.; et al. Circulating tumor DNA as a potential marker of adjuvant chemotherapy benefit following surgery for localized pancreatic cancer. Ann. Oncol. 2019, 30, 1472-1478. [CrossRef] [PubMed]

21. Parikh, A.R.; Leshchiner, I.; Elagina, L.; Goyal, L.; Levovitz, C.; Siravegna, G.; Livitz, D.; Rhrissorrakrai, K.; Martin, E.E.; Van Seventer, E.E.; et al. Liquid versus tissue biopsy for detecting acquired resistance and tumor heterogeneity in gastrointestinal cancers. Nat. Med. 2019, 25, 1415-1421. [CrossRef]

22. Russo, M.; Misale, S.; Wei, G.; Siravegna, G.; Crisafulli, G.; Lazzari, L.; Corti, G.; Rospo, G.; Novara, L.; Mussolin, B.; et al. Acquired Resistance to the TRK Inhibitor Entrectinib in Colorectal Cancer. Cancer Discov. 2016, 6, 36-44. [CrossRef] [PubMed]

23. Russo, M.; Siravegna, G.; Blaszkowsky, L.S.; Corti, G.; Crisafulli, G.; Ahronian, L.G.; Mussolin, B.; Kwak, E.L.; Buscarino, M.; Lazzari, L.; et al. Tumor Heterogeneity and Lesion-Specific Response to Targeted Therapy in Colorectal Cancer. Cancer Discov. 2016, 6, 147-153. [CrossRef]

24. Siravegna, G.; Mussolin, B.; Buscarino, M.; Corti, G.; Cassingena, A.; Crisafulli, G.; Ponzetti, A.; Cremolini, C.; Amatu, A.; Lauricella, C.; et al. Clonal evolution and resistance to EGFR blockade in the blood of colorectal cancer patients. Nat. Med. 2015, 21, 795-801. [CrossRef]

25. De Rubis, G.; Rajeev Krishnan, S.; Bebawy, M. Liquid Biopsies in Cancer Diagnosis, Monitoring, and Prognosis. Trends Pharmacol. Sci. 2019, 40, 172-186. [CrossRef]

26. Jiang, P.; Chan, C.W.; Chan, K.C.; Cheng, S.H.; Wong, J.; Wong, V.W.; Wong, G.L.; Chan, S.L.; Mok, T.S.; Chan, H.L.; et al. Lengthening and shortening of plasma DNA in hepatocellular carcinoma patients. Proc. Natl. Acad. Sci. USA 2015, 112, E1317-E1325. [CrossRef] [PubMed]

27. Labgaa, I.; Villacorta-Martin, C.; D'Avola, D.; Craig, A.J.; von Felden, J.; Martins-Filho, S.N.; Sia, D.; Stueck, A.; Ward, S.C.; Fiel, M.I.; et al. A pilot study of ultra-deep targeted sequencing of plasma DNA identifies driver mutations in hepatocellular carcinoma. Oncogene 2018, 37, 3740-3752. [CrossRef]

28. Cai, Z.; Chen, G.; Zeng, Y.; Dong, X.; Li, Z.; Huang, Y.; Xin, F.; Qiu, L.; Xu, H.; Zhang, W.; et al. Comprehensive Liquid Profiling of Circulating Tumor DNA and Protein Biomarkers in Long-Term Follow-Up Patients with Hepatocellular Carcinoma. Clin. Cancer Res. 2019, 25, 5284-5294. [CrossRef] [PubMed]

29. Oh, C.R.; Kong, S.Y.; Im, H.S.; Kim, H.J.; Kim, M.K.; Yoon, K.A.; Cho, E.H.; Jang, J.H.; Lee, J.; Kang, J.; et al. Genome-wide copy number alteration and VEGFA amplification of circulating cell-free DNA as a biomarker in advanced hepatocellular carcinoma patients treated with Sorafenib. BMC Cancer 2019, 19, 292. [CrossRef] [PubMed]

30. Ono, A.; Fujimoto, A.; Yamamoto, Y.; Akamatsu, S.; Hiraga, N.; Imamura, M.; Kawaoka, T.; Tsuge, M.; Abe, H.; Hayes, C.N.; et al. Circulating Tumor DNA Analysis for Liver Cancers and Its Usefulness as a Liquid Biopsy. Cell Mol. Gastroenterol. Hepatol. 2015, 1, 516-534. [CrossRef]

31. Liao, W.; Yang, H.; Xu, H.; Wang, Y.; Ge, P.; Ren, J.; Xu, W.; Lu, X.; Sang, X.; Zhong, S.; et al. Noninvasive detection of tumorassociated mutations from circulating cell-free DNA in hepatocellular carcinoma patients by targeted deep sequencing. Oncotarget 2016, 7, 40481-40490. [CrossRef]

32. Hann, H.W.; Jain, S.; Park, G.; Steffen, J.D.; Song, W.; Su, Y.H. Detection of urine DNA markers for monitoring recurrent hepatocellular carcinoma. Hepatoma Res. 2017, 3, 105-111. [CrossRef]

33. Jiao, J.; Watt, G.P.; Stevenson, H.L.; Calderone, T.L.; Fisher-Hoch, S.P.; Ye, Y.; Wu, X.; Vierling, J.M.; Beretta, L. Telomerase reverse transcriptase mutations in plasma DNA in patients with hepatocellular carcinoma or cirrhosis: Prevalence and risk factors. Hepatol. Commun. 2018, 2, 718-731. [CrossRef]

34. Oversoe, S.K.; Clement, M.S.; Pedersen, M.H.; Weber, B.; Aagaard, N.K.; Villadsen, G.E.; Gronbaek, H.; Hamilton-Dutoit, S.J.; Sorensen, B.S.; Kelsen, J. TERT promoter mutated circulating tumor DNA as a biomarker for prognosis in hepatocellular carcinoma. Scand. J. Gastroenterol. 2020, 55, 1433-1440. [CrossRef]

35. Kim, S.S.; Eun, J.W.; Choi, J.H.; Woo, H.G.; Cho, H.J.; Ahn, H.R.; Suh, C.W.; Baek, G.O.; Cho, S.W.; Cheong, J.Y. MLH1 singlenucleotide variant in circulating tumor DNA predicts overall survival of patients with hepatocellular carcinoma. Sci. Rep. 2020, 10, 17862. [CrossRef] 
36. Hirai, M.; Kinugasa, H.; Nouso, K.; Yamamoto, S.; Terasawa, H.; Onishi, Y.; Oyama, A.; Adachi, T.; Wada, N.; Sakata, M.; et al. Prediction of the prognosis of advanced hepatocellular carcinoma by TERT promoter mutations in circulating tumor DNA. J. Gastroenterol. Hepatol. 2020. [CrossRef] [PubMed]

37. Shen, T.; Li, S.F.; Wang, J.L.; Zhang, T.; Zhang, S.; Chen, H.T.; Xiao, Q.Y.; Ren, W.H.; Liu, C.; Peng, B.; et al. TP53 R249S mutation detected in circulating tumour DNA is associated with Prognosis of hepatocellular carcinoma patients with or without hepatectomy. Liver Int. 2020, 40, 2834-2847. [CrossRef]

38. von Felden, J.; Craig, A.J.; Garcia-Lezana, T.; Labgaa, I.; Haber, P.K.; D'Avola, D.; Asgharpour, A.; Dieterich, D.; Bonaccorso, A.; Torres-Martin, M.; et al. Mutations in circulating tumor DNA predict primary resistance to systemic therapies in advanced hepatocellular carcinoma. Oncogene 2020. [CrossRef]

39. Huang, Z.H.; Hu, Y.; Hua, D.; Wu, Y.Y.; Song, M.X.; Cheng, Z.H. Quantitative analysis of multiple methylated genes in plasma for the diagnosis and prognosis of hepatocellular carcinoma. Exp. Mol. Pathol. 2011, 91, 702-707. [CrossRef]

40. Xu, R.H.; Wei, W.; Krawczyk, M.; Wang, W.; Luo, H.; Flagg, K.; Yi, S.; Shi, W.; Quan, Q.; Li, K.; et al. Circulating tumour DNA methylation markers for diagnosis and prognosis of hepatocellular carcinoma. Nat. Mater. 2017, 16, 1155-1161. [CrossRef] [PubMed]

41. Lu, C.Y.; Chen, S.Y.; Peng, H.L.; Kan, P.Y.; Chang, W.C.; Yen, C.J. Cell-free methylation markers with diagnostic and prognostic potential in hepatocellular carcinoma. Oncotarget 2017, 8, 6406-6418. [CrossRef]

42. Yeh, C.C.; Goyal, A.; Shen, J.; Wu, H.C.; Strauss, J.A.; Wang, Q.; Gurvich, I.; Safyan, R.A.; Manji, G.A.; Gamble, M.V.; et al. Global Level of Plasma DNA Methylation is Associated with Overall Survival in Patients with Hepatocellular Carcinoma. Ann. Surg. Oncol. 2017, 24, 3788-3795. [CrossRef] [PubMed]

43. Li, F.; Qiao, C.Y.; Gao, S.; Fan, Y.C.; Chen, L.Y.; Wang, K. Circulating cell-free DNA of methylated insulin-like growth factorbinding protein 7 predicts a poor prognosis in hepatitis B virus-associated hepatocellular carcinoma after hepatectomy. Free Radic. Res. 2018, 52, 455-464. [CrossRef]

44. Chen, M.M.; Zhao, R.C.; Chen, K.F.; Huang, Y.; Liu, Z.J.; Wei, Y.G.; Jian, Y.; Sun, A.M.; Qin, L.; Li, B.; et al. Hypomethylation of CTCFL promoters as a noninvasive biomarker in plasma from patients with hepatocellular carcinoma. Neoplasma 2020, 67, 909-915. [CrossRef]

45. Chiang, D.Y.; Villanueva, A.; Hoshida, Y.; Peix, J.; Newell, P.; Minguez, B.; LeBlanc, A.C.; Donovan, D.J.; Thung, S.N.; Sole, M.; et al. Focal gains of VEGFA and molecular classification of hepatocellular carcinoma. Cancer Res. 2008, 68, 6779-6788. [CrossRef] [PubMed]

46. Schulze, K.; Imbeaud, S.; Letouze, E.; Alexandrov, L.B.; Calderaro, J.; Rebouissou, S.; Couchy, G.; Meiller, C.; Shinde, J.; Soysouvanh, F.; et al. Exome sequencing of hepatocellular carcinomas identifies new mutational signatures and potential therapeutic targets. Nat. Genet. 2015, 47, 505-511. [CrossRef]

47. Totoki, Y.; Tatsuno, K.; Covington, K.R.; Ueda, H.; Creighton, C.J.; Kato, M.; Tsuji, S.; Donehower, L.A.; Slagle, B.L.; Nakamura, H.; et al. Trans-ancestry mutational landscape of hepatocellular carcinoma genomes. Nat. Genet. 2014, 46, 1267-1273. [CrossRef]

48. Hernandez-Meza, G.; von Felden, J.; Gonzalez-Kozlova, E.E.; Garcia-Lezana, T.; Peix, J.; Portela, A.; Craig, A.J.; Sayols, S.; Schwartz, M.; Losic, B.; et al. DNA methylation profiling of human hepatocarcinogenesis. Hepatology 2020. [CrossRef]

49. Villanueva, A.; Portela, A.; Sayols, S.; Battiston, C.; Hoshida, Y.; Mendez-Gonzalez, J.; Imbeaud, S.; Letouze, E.; Hernandez-Gea, V.; Cornella, H.; et al. DNA methylation-based prognosis and epidrivers in hepatocellular carcinoma. Hepatology 2015, 61, 1945-1956. [CrossRef] [PubMed]

50. Koberle, V.; Kronenberger, B.; Pleli, T.; Trojan, J.; Imelmann, E.; Peveling-Oberhag, J.; Welker, M.W.; Elhendawy, M.; Zeuzem, S.; Piiper, A.; et al. Serum microRNA-1 and microRNA-122 are prognostic markers in patients with hepatocellular carcinoma. Eur. J. Cancer 2013, 49, 3442-3449. [CrossRef]

51. Xu, Y.; Bu, X.; Dai, C.; Shang, C. High serum microRNA-122 level is independently associated with higher overall survival rate in hepatocellular carcinoma patients. Tumour. Biol. 2015, 36, 4773-4776. [CrossRef] [PubMed]

52. Cho, H.J.; Kim, S.S.; Nam, J.S.; Kim, J.K.; Lee, J.H.; Kim, B.; Wang, H.J.; Kim, B.W.; Lee, J.D.; Kang, D.Y.; et al. Low levels of circulating microRNA-26a/29a as poor prognostic markers in patients with hepatocellular carcinoma who underwent curative treatment. Clin. Res. Hepatol. Gastroenterol. 2017, 41, 181-189. [CrossRef]

53. Ning, S.; Liu, H.; Gao, B.; Wei, W.; Yang, A.; Li, J.; Zhang, L. miR-155, miR-96 and miR-99a as potential diagnostic and prognostic tools for the clinical management of hepatocellular carcinoma. Oncol. Lett. 2019, 18, 3381-3387. [CrossRef] [PubMed]

54. Jin, Y.; Wong, Y.S.; Goh, B.K.P.; Chan, C.Y.; Cheow, P.C.; Chow, P.K.H.; Lim, T.K.H.; Goh, G.B.B.; Krishnamoorthy, T.L.; Kumar, R.; et al. Circulating microRNAs as Potential Diagnostic and Prognostic Biomarkers in Hepatocellular Carcinoma. Sci. Rep. 2019, 9 , 10464. [CrossRef]

55. Loosen, S.H.; Wirtz, T.H.; Roy, S.; Vucur, M.; Castoldi, M.; Schneider, A.T.; Koppe, C.; Ulmer, T.F.; Roeth, A.A.; Bednarsch, J.; et al. Circulating levels of microRNA193a-5p predict outcome in early stage hepatocellular carcinoma. PLoS ONE 2020, 15, e0239386. [CrossRef]

56. Pratedrat, P.; Chuaypen, N.; Nimsamer, P.; Payungporn, S.; Pinjaroen, N.; Sirichindakul, B.; Tangkijvanich, P. Diagnostic and prognostic roles of circulating miRNA-223-3p in hepatitis B virus-related hepatocellular carcinoma. PLoS ONE 2020, 15, e0232211. [CrossRef] 
57. Jeng, K.S.; Sheen, I.S.; Wang, Y.C.; Gu, S.L.; Chu, C.M.; Shih, S.C.; Wang, P.C.; Chang, W.H.; Wang, H.Y. Prognostic significance of preoperative circulating vascular endothelial growth factor messenger RNA expression in resectable hepatocellular carcinoma: A prospective study. World J. Gastroenterol. 2004, 10, 643-648. [CrossRef]

58. Morimoto, O.; Nagano, H.; Miyamoto, A.; Fujiwara, Y.; Kondo, M.; Yamamoto, T.; Ota, H.; Nakamura, M.; Wada, H.; Damdinsuren, B.; et al. Association between recurrence of hepatocellular carcinoma and alpha-fetoprotein messenger RNA levels in peripheral blood. Surg. Today 2005, 35, 1033-1041. [CrossRef]

59. Kong, S.Y.; Park, J.W.; Kim, J.O.; Lee, N.O.; Lee, J.A.; Park, K.W.; Hong, E.K.; Kim, C.M. Alpha-fetoprotein and human telomerase reverse transcriptase mRNA levels in peripheral blood of patients with hepatocellular carcinoma. J. Cancer Res. Clin. Oncol. 2009, 135, 1091-1098. [CrossRef] [PubMed]

60. Sugimachi, K.; Matsumura, T.; Hirata, H.; Uchi, R.; Ueda, M.; Ueo, H.; Shinden, Y.; Iguchi, T.; Eguchi, H.; Shirabe, K.; et al. Identification of a bona fide microRNA biomarker in serum exosomes that predicts hepatocellular carcinoma recurrence after liver transplantation. Br. J. Cancer 2015, 112, 532-538. [CrossRef] [PubMed]

61. Qu, Z.; Wu, J.; Wu, J.; Ji, A.; Qiang, G.; Jiang, Y.; Jiang, C.; Ding, Y. Exosomal miR-665 as a novel minimally invasive biomarker for hepatocellular carcinoma diagnosis and prognosis. Oncotarget 2017, 8, 80666-80678. [CrossRef]

62. Lee, Y.R.; Kim, G.; Tak, W.Y.; Jang, S.Y.; Kweon, Y.O.; Park, J.G.; Lee, H.W.; Han, Y.S.; Chun, J.M.; Park, S.Y.; et al. Circulating exosomal noncoding RNAs as prognostic biomarkers in human hepatocellular carcinoma. Int. J. Cancer 2019, 144, 1444-1452. [CrossRef] [PubMed]

63. Shi, M.; Jiang, Y.; Yang, L.; Yan, S.; Wang, Y.G.; Lu, X.J. Decreased levels of serum exosomal miR-638 predict poor prognosis in hepatocellular carcinoma. J. Cell Biochem. 2018, 119, 4711-4716. [CrossRef] [PubMed]

64. Tan, C.; Cao, J.; Chen, L.; Xi, X.; Wang, S.; Zhu, Y.; Yang, L.; Ma, L.; Wang, D.; Yin, J.; et al. Noncoding RNAs Serve as Diagnosis and Prognosis Biomarkers for Hepatocellular Carcinoma. Clin. Chem. 2019, 65, 905-915. [CrossRef] [PubMed]

65. Luo, Y.; Liu, F.; Gui, R. High expression of circulating exosomal circAKT3 is associated with higher recurrence in HCC patients undergoing surgical treatment. Surg. Oncol. 2020, 33, 276-281. [CrossRef]

66. Hao, X.; Xin, R.; Dong, W. Decreased serum exosomal miR-320a expression is an unfavorable prognostic factor in patients with hepatocellular carcinoma. J. Int. Med. Res. 2020, 48, 300060519896144. [CrossRef] [PubMed]

67. Lin, X.J.; Chong, Y.; Guo, Z.W.; Xie, C.; Yang, X.J.; Zhang, Q.; Li, S.P.; Xiong, Y.; Yuan, Y.; Min, J.; et al. A serum microRNA classifier for early detection of hepatocellular carcinoma: A multicentre, retrospective, longitudinal biomarker identification study with a nested case-control study. Lancet Oncol. 2015, 16, 804-815. [CrossRef]

68. Maisano, D.; Mimmi, S.; Russo, R.; Fioravanti, A.; Fiume, G.; Vecchio, E.; Nistico, N.; Quinto, I.; Iaccino, E. Uncovering the Exosomes Diversity: A Window of Opportunity for Tumor Progression Monitoring. Pharmaceuticals 2020, 13, 180. [CrossRef]

69. Hoshino, A.; Costa-Silva, B.; Shen, T.L.; Rodrigues, G.; Hashimoto, A.; Tesic Mark, M.; Molina, H.; Kohsaka, S.; Di Giannatale, A.; Ceder, S.; et al. Tumour exosome integrins determine organotropic metastasis. Nature 2015, 527, 329-335. [CrossRef]

70. Hoshino, A.; Kim, H.S.; Bojmar, L.; Gyan, K.E.; Cioffi, M.; Hernandez, J.; Zambirinis, C.P.; Rodrigues, G.; Molina, H.; Heissel, S.; et al. Extracellular Vesicle and Particle Biomarkers Define Multiple Human Cancers. Cell 2020, 182, 1044-1061.e1018. [CrossRef]

71. Costa-Silva, B.; Aiello, N.M.; Ocean, A.J.; Singh, S.; Zhang, H.; Thakur, B.K.; Becker, A.; Hoshino, A.; Mark, M.T.; Molina, H.; et al. Pancreatic cancer exosomes initiate pre-metastatic niche formation in the liver. Nat. Cell Biol. 2015, 17, 816-826. [CrossRef] [PubMed]

72. Iaccino, E.; Mimmi, S.; Dattilo, V.; Marino, F.; Candeloro, P.; Di Loria, A.; Marimpietri, D.; Pisano, A.; Albano, F.; Vecchio, E.; et al. Monitoring multiple myeloma by idiotype-specific peptide binders of tumor-derived exosomes. Mol. Cancer 2017, 16, 159. [CrossRef] [PubMed]

73. Nistico, N.; Maisano, D.; Iaccino, E.; Vecchio, E.; Fiume, G.; Rotundo, S.; Quinto, I.; Mimmi, S. Role of Chronic Lymphocytic Leukemia (CLL)-Derived Exosomes in Tumor Progression and Survival. Pharmaceuticals 2020, 13, 244. [CrossRef]

74. Cristofanilli, M.; Budd, G.T.; Ellis, M.J.; Stopeck, A.; Matera, J.; Miller, M.C.; Reuben, J.M.; Doyle, G.V.; Allard, W.J.; Terstappen, L.W.; et al. Circulating tumor cells, disease progression, and survival in metastatic breast cancer. N. Engl. J. Med. 2004, 351, 781-791. [CrossRef] [PubMed]

75. Sun, Y.F.; Xu, Y.; Yang, X.R.; Guo, W.; Zhang, X.; Qiu, S.J.; Shi, R.Y.; Hu, B.; Zhou, J.; Fan, J. Circulating stem cell-like epithelial cell adhesion molecule-positive tumor cells indicate poor prognosis of hepatocellular carcinoma after curative resection. Hepatology 2013, 57, 1458-1468. [CrossRef]

76. D'Avola, D.; Villacorta-Martin, C.; Martins-Filho, S.N.; Craig, A.; Labgaa, I.; von Felden, J.; Kimaada, A.; Bonaccorso, A.; Tabrizian, P.; Hartmann, B.M.; et al. High-density single cell mRNA sequencing to characterize circulating tumor cells in hepatocellular carcinoma. Sci. Rep. 2018, 8, 11570. [CrossRef] [PubMed]

77. Vona, G.; Estepa, L.; Beroud, C.; Damotte, D.; Capron, F.; Nalpas, B.; Mineur, A.; Franco, D.; Lacour, B.; Pol, S.; et al. Impact of cytomorphological detection of circulating tumor cells in patients with liver cancer. Hepatology 2004, 39, 792-797. [CrossRef]

78. Xu, W.; Cao, L.; Chen, L.; Li, J.; Zhang, X.F.; Qian, H.H.; Kang, X.Y.; Zhang, Y.; Liao, J.; Shi, L.H.; et al. Isolation of circulating tumor cells in patients with hepatocellular carcinoma using a novel cell separation strategy. Clin. Cancer Res. 2011, 17, 3783-3793. [CrossRef] [PubMed]

79. Fan, S.T.; Yang, Z.F.; Ho, D.W.; Ng, M.N.; Yu, W.C.; Wong, J. Prediction of posthepatectomy recurrence of hepatocellular carcinoma by circulating cancer stem cells: A prospective study. Ann. Surg. 2011, 254, 569-576. [CrossRef] 
80. Cheng, S.W.; Tsai, H.W.; Lin, Y.J.; Cheng, P.N.; Chang, Y.C.; Yen, C.J.; Huang, H.P.; Chuang, Y.P.; Chang, T.T.; Lee, C.T.; et al. Lin28B is an oncofetal circulating cancer stem cell-like marker associated with recurrence of hepatocellular carcinoma. PLoS ONE 2013, 8, e80053. [CrossRef]

81. Liu, S.; Li, N.; Yu, X.; Xiao, X.; Cheng, K.; Hu, J.; Wang, J.; Zhang, D.; Cheng, S.; Liu, S. Expression of intercellular adhesion molecule 1 by hepatocellular carcinoma stem cells and circulating tumor cells. Gastroenterology 2013, 144, 1031-1041.e1010. [CrossRef]

82. Schulze, K.; Gasch, C.; Staufer, K.; Nashan, B.; Lohse, A.W.; Pantel, K.; Riethdorf, S.; Wege, H. Presence of EpCAM-positive circulating tumor cells as biomarker for systemic disease strongly correlates to survival in patients with hepatocellular carcinoma. Int. J. Cancer 2013, 133, 2165-2171. [CrossRef]

83. Guo, W.; Yang, X.R.; Sun, Y.F.; Shen, M.N.; Ma, X.L.; Wu, J.; Zhang, C.Y.; Zhou, Y.; Xu, Y.; Hu, B.; et al. Clinical significance of EpCAM mRNA-positive circulating tumor cells in hepatocellular carcinoma by an optimized negative enrichment and qRT-PCR-based platform. Clin. Cancer Res. 2014, 20, 4794-4805. [CrossRef]

84. Li, J.; Shi, L.; Zhang, X.; Sun, B.; Yang, Y.; Ge, N.; Liu, H.; Yang, X.; Chen, L.; Qian, H.; et al. pERK/pAkt phenotyping in circulating tumor cells as a biomarker for sorafenib efficacy in patients with advanced hepatocellular carcinoma. Oncotarget 2016, 7, 2646-2659. [CrossRef]

85. Jin, J.; Niu, X.; Zou, L.; Li, L.; Li, S.; Han, J.; Zhang, P.; Song, J.; Xiao, F. AFP mRNA level in enriched circulating tumor cells from hepatocellular carcinoma patient blood samples is a pivotal predictive marker for metastasis. Cancer Lett. 2016, 378, 33-37. [CrossRef]

86. Ogle, L.F.; Orr, J.G.; Willoughby, C.E.; Hutton, C.; McPherson, S.; Plummer, R.; Boddy, A.V.; Curtin, N.J.; Jamieson, D.; Reeves, H.L. Imagestream detection and characterisation of circulating tumour cells-A liquid biopsy for hepatocellular carcinoma? J. Hepatol. 2016, 65, 305-313. [CrossRef] [PubMed]

87. von Felden, J.; Schulze, K.; Krech, T.; Ewald, F.; Nashan, B.; Pantel, K.; Lohse, A.W.; Riethdorf, S.; Wege, H. Circulating tumor cells as liquid biomarker for high HCC recurrence risk after curative liver resection. Oncotarget 2017, 8, 89978-89987. [CrossRef] [PubMed]

88. Wang, L.; Li, Y.; Xu, J.; Zhang, A.; Wang, X.; Tang, R.; Zhang, X.; Yin, H.; Liu, M.; Wang, D.D.; et al. Quantified postsurgical small cell size CTCs and EpCAM(+) circulating tumor stem cells with cytogenetic abnormalities in hepatocellular carcinoma patients determine cancer relapse. Cancer Lett. 2018, 412, 99-107. [CrossRef]

89. Hao, S.; Chen, S.; Tu, C.; Huang, T. Anterior Approach to Improve the Prognosis in HCC Patients Via Decreasing Dissemination of EpCAM(+) Circulating Tumor Cells. J. Gastrointest Surg. 2017, 21, 1112-1120. [CrossRef]

90. Sun, Y.F.; Guo, W.; Xu, Y.; Shi, Y.H.; Gong, Z.J.; Ji, Y.; Du, M.; Zhang, X.; Hu, B.; Huang, A.; et al. Circulating Tumor Cells from Different Vascular Sites Exhibit Spatial Heterogeneity in Epithelial and Mesenchymal Composition and Distinct Clinical Significance in Hepatocellular Carcinoma. Clin. Cancer Res. 2018, 24, 547-559. [CrossRef] [PubMed]

91. Guo, W.; Sun, Y.F.; Shen, M.N.; Ma, X.L.; Wu, J.; Zhang, C.Y.; Zhou, Y.; Xu, Y.; Hu, B.; Zhang, M.; et al. Circulating Tumor Cells with Stem-Like Phenotypes for Diagnosis, Prognosis, and Therapeutic Response Evaluation in Hepatocellular Carcinoma. Clin. Cancer Res. 2018, 24, 2203-2213. [CrossRef] [PubMed]

92. Qi, L.N.; Xiang, B.D.; Wu, F.X.; Ye, J.Z.; Zhong, J.H.; Wang, Y.Y.; Chen, Y.Y.; Chen, Z.S.; Ma, L.; Chen, J.; et al. Circulating Tumor Cells Undergoing EMT Provide a Metric for Diagnosis and Prognosis of Patients with Hepatocellular Carcinoma. Cancer Res. 2018, 78, 4731-4744. [CrossRef]

93. Court, C.M.; Hou, S.; Winograd, P.; Segel, N.H.; Li, Q.W.; Zhu, Y.; Sadeghi, S.; Finn, R.S.; Ganapathy, E.; Song, M.; et al. A novel multimarker assay for the phenotypic profiling of circulating tumor cells in hepatocellular carcinoma. Liver Transpl. 2018, 24, 946-960. [CrossRef]

94. Yu, J.J.; Xiao, W.; Dong, S.L.; Liang, H.F.; Zhang, Z.W.; Zhang, B.X.; Huang, Z.Y.; Chen, Y.F.; Zhang, W.G.; Luo, H.P.; et al. Effect of surgical liver resection on circulating tumor cells in patients with hepatocellular carcinoma. BMC Cancer 2018, 18, 835. [CrossRef]

95. Ha, Y.; Kim, T.H.; Shim, J.E.; Yoon, S.; Jun, M.J.; Cho, Y.H.; Lee, H.C. Circulating tumor cells are associated with poor outcomes in early-stage hepatocellular carcinoma: A prospective study. Hepatol. Int. 2019, 13, 726-735. [CrossRef] [PubMed]

96. Hamaoka, M.; Kobayashi, T.; Tanaka, Y.; Mashima, H.; Ohdan, H. Clinical significance of glypican-3-positive circulating tumor cells of hepatocellular carcinoma patients: A prospective study. PLoS ONE 2019, 14, e0217586. [CrossRef]

97. Chen, Z.; Lin, X.; Chen, C.; Chen, Y.; Zhao, Q.; Wu, L.; Wang, D.; Ma, Y.; Ju, W.; Chen, M.; et al. Analysis of preoperative circulating tumor cells for recurrence in patients with hepatocellular carcinoma after liver transplantation. Ann. Transl. Med. 2020, 8, 1067. [CrossRef]

98. Zhou, J.; Zhang, Z.; Zhou, H.; Leng, C.; Hou, B.; Zhou, C.; Hu, X.; Wang, J.; Chen, X. Preoperative circulating tumor cells to predict microvascular invasion and dynamical detection indicate the prognosis of hepatocellular carcinoma. BMC Cancer 2020, 20, 1047. [CrossRef]

99. Winograd, P.; Hou, S.; Court, C.M.; Lee, Y.T.; Chen, P.J.; Zhu, Y.; Sadeghi, S.; Finn, R.S.; Teng, P.C.; Wang, J.J.; et al. Hepatocellular Carcinoma-Circulating Tumor Cells Expressing PD-L1 Are Prognostic and Potentially Associated With Response to Checkpoint Inhibitors. Hepatol. Commun. 2020, 4, 1527-1540. [CrossRef] [PubMed]

100. Wang, P.X.; Sun, Y.F.; Zhou, K.Q.; Cheng, J.W.; Hu, B.; Guo, W.; Yin, Y.; Huang, J.F.; Zhou, J.; Fan, J.; et al. Circulating tumor cells are an indicator for the administration of adjuvant transarterial chemoembolization in hepatocellular carcinoma: A single-center, retrospective, propensity-matched study. Clin. Transl. Med. 2020, 10, e137. [CrossRef] 
101. Wang, P.X.; Xu, Y.; Sun, Y.F.; Cheng, J.W.; Zhou, K.Q.; Wu, S.Y.; Hu, B.; Zhang, Z.F.; Guo, W.; Cao, Y.; et al. Detection of circulating tumour cells enables early recurrence prediction in hepatocellular carcinoma patients undergoing liver transplantation. Liver Int. 2020. [CrossRef] [PubMed]

102. Yamashita, T.; Forgues, M.; Wang, W.; Kim, J.W.; Ye, Q.; Jia, H.; Budhu, A.; Zanetti, K.A.; Chen, Y.; Qin, L.X.; et al. EpCAM and alpha-fetoprotein expression defines novel prognostic subtypes of hepatocellular carcinoma. Cancer Res. 2008, 68, $1451-1461$. [CrossRef]

103. Dent, B.M.; Ogle, L.F.; O’Donnell, R.L.; Hayes, N.; Malik, U.; Curtin, N.J.; Boddy, A.V.; Plummer, E.R.; Edmondson, R.J.; Reeves, H.L.; et al. High-resolution imaging for the detection and characterisation of circulating tumour cells from patients with oesophageal, hepatocellular, thyroid and ovarian cancers. Int. J. Cancer 2016, 138, 206-216. [CrossRef]

104. Toso, C.; Mentha, G.; Majno, P. Liver transplantation for hepatocellular carcinoma: Five steps to prevent recurrence. Am. J. Transplant. 2011, 11, 2031-2035. [CrossRef] [PubMed]

105. Cui, K.; Ou, Y.; Shen, Y.; Li, S.; Sun, Z. Clinical value of circulating tumor cells for the diagnosis and prognosis of hepatocellular carcinoma (HCC): A systematic review and meta-analysis. Medicine (Baltimore) 2020, 99, e22242. [CrossRef] [PubMed]

106. Yan, J.; Fan, Z.; Wu, X.; Xu, M.; Jiang, J.; Tan, C.; Wu, W.; Wei, X.; Zhou, J. Circulating tumor cells are correlated with disease progression and treatment response in an orthotopic hepatocellular carcinoma model. Cytometry A 2015, 87, 1020-1028. [CrossRef]

107. Gasparello, J.; Allegretti, M.; Tremante, E.; Fabbri, E.; Amoreo, C.A.; Romania, P.; Melucci, E.; Messana, K.; Borgatti, M.; Giacomini, P.; et al. Liquid biopsy in mice bearing colorectal carcinoma xenografts: Gateways regulating the levels of circulating tumor DNA (ctDNA) and miRNA (ctmiRNA). J. Exp. Clin. Cancer Res. 2018, 37, 124. [CrossRef] [PubMed]

108. Losic, B.; Craig, A.J.; Villacorta-Martin, C.; Martins-Filho, S.N.; Akers, N.; Chen, X.; Ahsen, M.E.; von Felden, J.; Labgaa, I.; D'Avola, D.; et al. Intratumoral heterogeneity and clonal evolution in liver cancer. Nat. Commun. 2020, 11, 291. [CrossRef] 